\title{
Social Networking Sites (SNS) and Family Relationship: A Study on Youths of Dhaka City
}

\author{
Saida Sultana \\ Department of Arts \& Sciences, Ahsanullah University of Science \& Technology, Bangladesh
}

\begin{abstract}
This study is designed to inspect whether greater use of the social networking sites is associated with the declining family relationship among the youth internet users of Dhaka city. The major hypotheses of this study are: (a) Use of social networking site is negatively related to family cohesion. (b) Those who spend more time on internet spend less time with their parents. The study used quantitative method of data collection. The sample consisted of 384 youth internet users in Dhaka city. Results of chi-square, correlation and logistic regression analysis suggests that, use of social networking sites is strongly associated all with components of family relationship. The overall findings of this study suggests that the greater use of the social networking sites is highly influential to the breakdown of family relationship.
\end{abstract}

Keywords: - Family, internet, social networking sites, youth, family cohesion.

\section{INTRODUCTION}

Social networking sites have become the most popular online destinations in recent years. One of the main concerns over the use of social networking sites is that as people spend more and more time communicating online and handling their daily tasks in cyberspace, it may be that they spend less time interacting with one another in the physical world (Giddens, 2006 [1]). Some sociologists fear that the spread of Internet technology will lead to increased social isolation and atomization. They argue that one effect of increasing use of social networking sites in households is that people are spending "less quality time" with their family and friends.

In recent years, with the increased use of social networking site, an interest in its social impact on everyday life has developed (Bargh et al. 2002 [2]). A substantial body of literature examined both the frequency and types of youth social networking site use and their relationships with parents (Glaser et al. 2002 [3]). This study endeavors to discover whether there is any relationship between family relationship and use of social networking sites among the youth internet users of Dhaka city. Youth of our country most often use social networking sites to connect with friends and to build communities, something they are also doing offline. Nevertheless, risks lie in communication with dangerous strangers, lack of face-to-face interaction, and the weakening of family ties. Much research needs to be done in this field before making any conclusive assumptions. Most researchers have focused on broad descriptions of trends in the use of the internet, such as time spent using computers and the internet (Hughes and Hans, 2001 [4]) and the ways in which children and adults use these technologies (Orleans \& Laney, 2000 [5]). Few researchers have examined the ways in which internet has altered family functionality.

\subsection{Statement of the Problem}

Like many developed and developing countries, Bangladesh has witnessed a phenomenal growth in accessing digital technology particularly using of internet. Social networking sites are a type of virtual community that has grown tremendously in popularity over the past few years in our country. These sites (i.e. Facebook, LinkedIn, Instagram) are an appendage of the new wave of the internet. Users create their own profiles - a virtual persona - and use their profile to list their favorite music, movies, and television, as well as upload their own pictures, video and music. Because of this ability to create an identity, social networking has become an essential part of the lives of adolescents and young adults, the most frequent users of these sites.

With the ever increasing usage of these social networking sites, the young group of people are becoming more dependent of the virtual relationships sacrificing their family and social values. Very recently, Bangladesh saw some ruthless criminal activities which are closely related to the unhealthy family relationships. Number of these type of crime is increasing at alarming rate.

\subsection{Importance of the Study}

This study was a partially exploratory effort to measure the impact of social networking sites on family relationship. This study has implications both for researchers and for all those involved in the lives of youth. 
The input of this piece of writing mainly involve a new evidence to answer the key question: does social networking sites use affect people's family relations? The goal of this study was to investigate the effect of frequency and type of social networking sites use by youth on family relation. Social networking sites use and family relationship of the concerned respondents would be explained using quantitative data. For this, some hypotheses are formulated reviewing related literatures deducting from few theoretical frameworks. Since the massive popularity of social networking sites come about until the early 2000s, research in this field is obviously incredibly young and there is still much to be done. This exploratory research purports to progressively narrow the research topic and to transform discovered problems into defined ones.

\subsection{Aims and Objectives of the Study}

The broad objective of the study is to explore whether the use of social networking sites declines family relationship of the youth of Dhaka city. The specific objectives of this study are as follows:

* To understand the feeling of closeness and emotional attachment of the social networking sites' users with their parents.

* To explore whether internet use decreases family time.

\subsection{Research Hypotheses}

- Social networking site use is negatively related to family cohesion.

* Those who spend more time on internet spend less time with their parents.

\section{LITERATURE REVIEW}

On no issue has research on the social effects of the Internet been more contentious than as to its effect on close relationships, such as those with family and friends. One study that received considerable media attention was the large-scale survey reported by Nie and Erbring (2000 [6]). This study concluded that Internet use led to negative outcomes for the individualizer, such as increases in depression and loneliness, and neglect of existing close relationships. In the press release, Nie \& Erbring (2000) reported data from a U.S. nationwide survey of approximately 4000 people, and concluded from those data that heavy Internet use resulted in less time spent with one's family and friends.

Several scholars suggest potential intergenerational conflicts in families that have adopted the Internet (Turow and Nir, 2000 [7]). One common explanation is the development of expectation gaps between parents and youth. Studies have shown that most parents seem to view the Internet as a positive new force in children's lives, and surveys in different countries report that families buy computers and connect their children to the Internet at home mainly for educational purposes (Lenhart et al. 2001 [8]). Many parents believe that the Internet can help their children to do better at school, do more thorough research for homework, and help them learn worthwhile things. Livingstone (2002) [9] found that only 6\% of parents were concerned about their children's use of computers and the Internet. Parents were far more concerned about illegal drugs (51\%), crime (39\%), and educational standards (38\%). These data suggest that when viewed in the context of other hazards children face, parents perceive that there are more serious threats to children's well-being than their children's computer and Internet use. However, 50\% of the parents in Livingstone's (2000) study reported having rules about children's use of the Internet. In contrast, children reported about half as many restrictions as their parents. The inconsistency between reports of parents and of their children points to a need for a better understanding of computers and Internet use in family contexts on a day-to-day basis. This may require observational and longitudinal data in addition to self-report by children and parents.

The contextual nature of parents' Internet concerns compared with their concerns about other aspects of life illustrates the importance of studying the Internet in context to provide a more complete understanding of how the technology fits with other aspects of family life. When the Internet is studied in isolation, it is easy to misunderstand how it fits with other aspects of family life and to distort its significance and influence. These studies provide a glimpse into the variety of ways that computers and the Internet may affect relationships in families. Whether they have a positive or negative impact on family interactions is a complicated question that requires more research and the consideration of how other household technologies, such as cell phones, video games, and television, foster or hinder family communication, conflict, and socialization. When youth use the Internet for social and entertainment purposes, parental expectations presumably contradict that kind of use, which increases the conflicts between adolescents and parents. Conversely, using the Internet for learning and educational purposes, a use that is highly valued by parents and consistent with parental expectations, will presumably be negatively associated with family conflicts (Mesch, 2003 [10]). An explanation is time displacement: It has been argued that Internet use is negatively associated with family time. The main contention is that time spent on one activity cannot be spent on another. Internet use is a time-consuming activity, and in families that are connected to the Internet, high frequency of use might be negatively associated with family time and positively associated with family conflicts. 
In fact, parents and adolescents worry that Internet use might have a negative effect on family communication and closeness. This concern has received empirical support from a recent study, which, based on family time diaries, found that Internet use at home was negatively related to time spent with family. Furthermore, the reduction in family time was higher for the average Internet user than for the average TV watcher. As well as the amount, the quality of family time also appears associated with Internet use. Recent studies that investigated the effect of frequency of daily Internet use by adolescents on the quality of their relationships with parents and friends found that low Internet use was associated with better relationships with parents and friends than was high Internet use (Mesch, 2003). Furthermore, adolescents report that Internet use does not help them to improve their relationships with their parents and that the Internet consumes time they would spend with their families. Other studies present different evidence on the effects of the Internet on family time and suggest that rather than isolating children from their parents the Internet has become a shared household activity (Kaiser Family Foundation, 2003 [11]). In one study, nearly half the parents reported spending at least some time each week using the Internet with other household members, and only a quarter of the adults reported that they never spent time with other household members on the Internet. When asked if they felt ignored because a household member spent too much time on the Internet, more than three fourths of respondents said they did not. Furthermore when comparing responses of Internet users and Internet non-users, no significant differences were found between these two groups in the extent of agreement that members of the family listened to each other, were too busy to talk to each other, and shared ideas with each other (Cole et al. 2000 [12]). In sum, empirical evidence on the association between Internet use and family time is mixed. In addition, to the best of our knowledge no study has investigated how Internet use and its association with family time are related, if at all, to family cohesion.

\section{METHODOLOGY}

This exploratory research utilized quantitative method including structured survey to collect data. The exploratory research purports to progressively narrow the scope of the research topic and to transform discovered problems into defined ones. The basic drive is to provide information to use in analyzing the situation regarding social networking site and family relationship.

\subsection{Sampling Procedure and Sample Size Determination}

The study was conducted among students of seven educational institutions within Dhaka Metropolitan area. A structured questionnaire was administered in order to obtain quantitative data from the sampled respondents. With an aim to organize work in a representative manner, seven educational institutions were selected based on the presumptions that these institutions have the highest number of possible respondents this study required. Probability sampling approach was followed for conducting survey for this study. Particularly simple random sampling was followed to draw sample for the survey.

\subsection{Measurement of the Variables}

Measurement, in turn, is intimately related to two processes: conceptualization and operationalization. Conceptualization is the process of taking a construct or concept and refining it by giving it a conceptual or theoretical definition. Operationalization is taking a conceptual definition and making it more precise by linking it to one or more specific, concrete indicators or operational definitions. Variables for this study are carefully selected and measured so that they support researcher to validate the hypotheses.

3.2.1. Demographic profile: Demographic profile of the respondents has been measured by the certain criteria (1) Gender of the respondents (2) Age of the respondents (3) Level of education (4) Medium of study (5) Marital status (4) Family type.

3.2.2. Exposure to Internet: Respondents' exposure to internet was measured by certain questions on: (1) Frequency of the use of internet in a month (2) Frequency of the use of internet every day.

3.2.3. Types of Social Networking Sites Users: In order to analysis social networking site users, users were divided among three classes:

- Non-user

- Low user

- High user

Respondents who don't have any kind of social networking sites account are non-users of social networking sites. Social networking sites users were defined by two questions: (a) if you use SNS how often do you use it for? (b) If you use SNS how many hours do you use it for everyday? Respondents who use social 
networking sites everyday but use it for only less than two hours were considered as low users of social networking sites. On the other hand high users were considered.

3.2.4. Family Time: Family time was measured by hours respondents use to spend with their parents. Respondents who spend less than two hours with their parents every day and on holiday were viewed as low time spend in measure. On the other hand respondents who spend more than two hours with parents every day and holiday were viewed as giving high time spend with their parents.

3.2.5. Cohesion with Parents: Cohesion with parents was measured by some statements such as my parents are attentive to my problems, my parents and I are emotionally close, and my parents trust my judgment. Respondents who agree or strongly agree with these statements were considered as having high cohesion with their parents and on the other hand respondents who disagree or strongly disagree with these statements were viewed as having low cohesion with their parents.

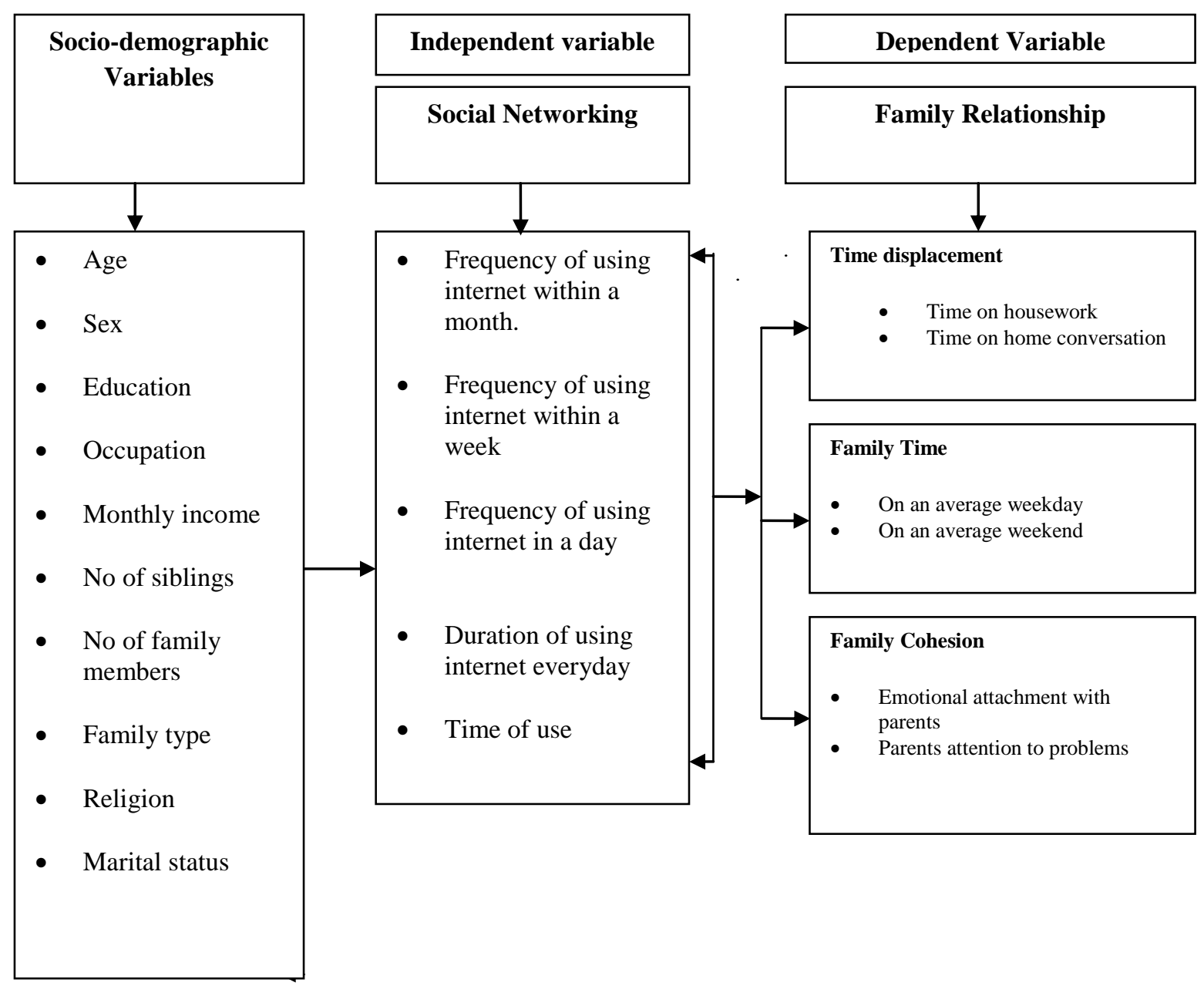

Figure-1: Conceptual Framework

\section{DATA ANALYSIS \& FINDINGS}

4.1. Internet Use and Family Time:

To observe the relationship between internet use and family time, findings of univariate, bivariate and multivariate are presented in this section.

4.1.1. Respondents' Family Time

Table-1: Respondents' Distribution of Spending Time with Parents' Everyday

\begin{tabular}{|c|c|}
\hline Spending time with parents everyday & Percentage \\
\hline Less than one hour & 25 \\
\hline $1-2$ hours & 32 \\
\hline
\end{tabular}




\begin{tabular}{|c|c|}
\hline 2-3 hours & 17 \\
\hline 3-4 hours & 22 \\
\hline More than 4 hours & 4 \\
\hline Total & 100 \\
\hline
\end{tabular}

From the Table-1, it is seen that most of the respondents (32\%) spend for 1-2 hours with their parents everyday and only 4 percent respondents spend more than 4 hours with their parents every day.

Table-2: Respondents' Distribution of Spending Time with Parents' Holiday

\begin{tabular}{|c|c|}
\hline Spending time with parents holiday & Percentage \\
\hline Less than one hour & 28 \\
\hline 1-2 hours & 29 \\
\hline $2-3$ hours & 7 \\
\hline 3-4 hours & 21 \\
\hline More than 4 hours & 15 \\
\hline Total & 100 \\
\hline
\end{tabular}

From the Table- 2, it is depicted that majority of the respondents (29\%) spend for 1-2 hours with their parents on holiday and only 7 percent respondents spend 2-3 hours with their parents on holiday.

4.1.2. Association between Internet Use and Family Time

Table- 3: Summary Table of Chi-square and Cramer's V on Components of spending Time with Parents by Internet Use

\begin{tabular}{|c|c|c|}
\hline \multirow{2}{*}{$\begin{array}{c}\text { Items of Internet } \\
\text { use }\end{array}$} & \multicolumn{2}{|c|}{ Components of family time } \\
\cline { 2 - 3 } & Spending time with parents everyday & $\begin{array}{c}\text { Spending time with } \\
\text { parents on holiday }\end{array}$ \\
\hline $\begin{array}{c}\text { Type of Internet } \\
\text { user }\end{array}$ & $\mathrm{X}^{2}=26.039, \mathrm{df}=8$ & $\mathrm{X}^{2}=29.339, \mathrm{df}=8$ \\
\cline { 2 - 3 } Using at night & $\alpha=.001$ & $\alpha=.001$ \\
\cline { 2 - 3 } & $\mathrm{X}^{2}=5.21, \mathrm{df}=4$ & $\mathrm{X}^{2}=18.694, \mathrm{df}=4$ \\
\hline $\begin{array}{c}\text { Using at late } \\
\text { night }\end{array}$ & $\alpha=.266$ & $\alpha=.001$ \\
\cline { 2 - 3 } & $\mathrm{X}^{2}=13.156, \mathrm{df}=4$ & $\mathrm{X}^{2}=14.269, \mathrm{df}=4$ \\
\hline
\end{tabular}

The Table- 3, which gives Chi-square and Cramer's V values indicates that types of SNS users strongly related to all components of family time. This table also portrays that the use of internet at night is not related to spending time with parents everyday but there is a strong association between the use of internet at night and spending time with parents' holiday. Use of Internet at late night is associated with all components of family time.

\subsection{Social Networking Sites' Use and Family Cohesion}

To explore the relationship between social networking site use and cohesion with parents, univariate and bivariate results are presented here.

\subsubsection{Respondents' Family Cohesion}

To understand respondents' bonding with their parents, respondents were asked their level of agreement with some statements.

Table- 4: Respondents Level of Agreement with the Statements of Cohesion with their Parents

\begin{tabular}{|l|c|}
\hline $\begin{array}{c}\text { My parents are attentive to } \\
\text { my problems }\end{array}$ & Percent \\
\hline Strong Disagree & 21 \\
\hline Disagree & 6 \\
\hline Neither agree nor disagree & 15 \\
\hline
\end{tabular}

\begin{tabular}{|l|c|}
\hline $\begin{array}{l}\text { My parents and I are } \\
\text { emotionally close }\end{array}$ & Percent \\
\hline Strong Disagree & 15 \\
\hline Disagree & 14 \\
\hline Neither agree nor disagree & 19 \\
\hline
\end{tabular}




\begin{tabular}{|c|c|c|c|}
\hline Agree & 32 & Agree & 30 \\
\hline Strongly Agree & 26 & Strongly Agree & 22 \\
\hline Total & 100 & Total & 100 \\
\hline
\end{tabular}

Table- 4 shows that, when respondents were asked the statement "My parents are attentive to my problems", $58 \%$ of the respondents provided positive results (either agree or strongly agree), only $27 \%$ provided negative answers and $15 \%$ remained indifferent.

Table- 4 also demonstrates that, when respondents were asked their agreement "My parents and I are emotionally close" $52 \%$ of the respondents provided positive results (either agree or strongly agree), only $29 \%$ provided negative answers and $19 \%$ remained indifferent.

\subsubsection{Association between SNS Use and Family Cohesion}

Table- 5 gives Chi-square and Cramer's V values of social networking sites' use and family cohesion.

Table- 5: Summary Table of Chi-square and Cramer's V Components of Cohesion with Parents by Social Networking Sites' Use

\begin{tabular}{|c|c|c|c|}
\hline \multirow{2}{*}{$\begin{array}{c}\text { Items of social } \\
\text { networking sites } \\
\text { use }\end{array}$} & \multicolumn{2}{|c|}{ Cohesion with Parents } \\
\cline { 2 - 4 } & $\begin{array}{c}\text { My parents are attentive } \\
\text { to my problems }\end{array}$ & $\begin{array}{c}\text { My parents and I are } \\
\text { emotionally close }\end{array}$ & $\begin{array}{c}\text { My parents trust } \\
\text { my judgment }\end{array}$ \\
\hline \multirow{2}{*}{ Types of SNS users } & $\mathrm{X}^{2}=1.31, \mathrm{df}=8$ & $\mathrm{X}^{2}=1.30, \mathrm{df}=8$ & $\mathrm{X}^{2}=1.29, \mathrm{df}=8$ \\
\cline { 2 - 4 } & $\alpha=.01$ & $\alpha=.001$ & $\alpha=.001$ \\
\hline \multirow{2}{*}{ Using at night } & $\mathrm{X}^{2}=19.831, \mathrm{df}=4$ & $\mathrm{X}^{2}=28.136, \mathrm{df}=4$ & $\mathrm{X}^{2}=25.856, \mathrm{df}=4$ \\
\cline { 2 - 4 } & $\alpha=.001$ & $\alpha=.001$ & $\alpha=.01$ \\
\hline \multirow{2}{*}{ Using at late night } & $\mathrm{X}^{2}=6.269, \mathrm{df}=4$ & $\mathrm{X}^{2}=5.196, \mathrm{df}=4$ & $\mathrm{X}^{2}=7.378, \mathrm{df}=4$ \\
\cline { 2 - 4 } & $\alpha=.180$ & $\alpha=.268$ & $\alpha=.117$ \\
\hline
\end{tabular}

Table- 5 presented above demonstrates that all indicators of cohesion with parents are strongly influenced by types of SNS users. Chi-square values also indicate that there is strong association between the use of SNS at night and components of parental cohesion. It is evident from the table that there is no association between the use of SNS at late night and components of cohesion with parents.

\subsubsection{Comparative Analysis: SNS Users and Family Cohesion}

Table- 6: Cross Tabulation on Cohesion with Parents by SNS Use (in percent) N=384

\begin{tabular}{|c|c|c|c|c|c|}
\hline \multirow[b]{2}{*}{ Cohesion with parents } & \multicolumn{3}{|c|}{ Types of SNS users } & \multirow[b]{2}{*}{ Total } & \multirow[b]{2}{*}{$\mathbf{N}$} \\
\hline & Non user & Low user & $\begin{array}{c}\text { High } \\
\text { user }\end{array}$ & & \\
\hline Low cohesion & 11 & 15 & 74 & 100 & 103 \\
\hline Moderate cohesion & 24 & 28 & 48 & 100 & 54 \\
\hline High Cohesion & 16 & 64 & 20 & 100 & 227 \\
\hline Total N & 61 & 176 & 147 & & 384 \\
\hline \multicolumn{6}{|c|}{$\mathrm{X}^{2}=100.150, \mathrm{df}=4 \alpha=.001$} \\
\hline
\end{tabular}

The above Table- 6 portrays that, those who have low cohesion with parents among them majority of the respondents (74\%) are high users. On contrary, those who have high cohesion with parents among them majority of the respondents $(64 \%)$ are low users. The significant chi-square value indicates that social networking sites' use and cohesion with parents strongly associated with each other.

Table- 7: Correlation Table Cohesion with Parents by Social Networking Site

\begin{tabular}{|l|l|}
\hline $\begin{array}{l}\text { Cohesion with parents by Social Networking } \\
\text { Site Use }\end{array}$ & $\mathrm{r}=-.362, \alpha=.001$ \\
\hline
\end{tabular}


It is seen from the Table- 7 that the value of correlation coefficient, $r=-.362$, which implies that there is a strong negative association between the variables; social networking site use and cohesion with parents.

\section{CONCLUSION}

The present study is conducted to examine the relationship between social networking sites' use and family relationship. To fulfill this purpose of the analysis the study has examined different types of social networking sites' users and the pattern of family relationship they have. Family relationship is measured through the respondent's spending amount of time with their family, by cohesion with parents. A major finding of this study highlighted that people who spend more time on internet spend less time with their parents. From the cross tabulation it has found that among high internet users around three forth portion spend less time with parents. From the logistic regression analysis, it is also found that high family time likely to occur 8.612 times among low internet users than high internet users. The main finding of this study is the existence of different pathways that link the extent of social networking site use and cohesion with parents. The significant chi-square value of this study indicates that there is a strong association between cohesion with parents and social networking site use. From the cross tabulation it is depicted that among low social networking sites' users around forth portion of respondents have high cohesion with parents. On the other hand among high social networking sites' users, above fifty percent have low cohesion with their parents. Social Networking sites like Facebook, LinkedIn, Instagram became common destination for young people in our country. Throughout the country young people are logging in, creating elaborate profiles and writing extensive comments back and forth. So the impact of Social Network Sites and its impact on family relationship is a major issue to uncover the hidden truth of excessive use of Social Networking Sites and its relationship with family life. From the study, it reveals that although Bangladesh is a developing country the technological impact on youth is enormous. Like Western Societies, in our country over use of Social Networking Sites leads to the decline of family relationship by decreasing the time youth spend with their parents, by decreasing their social circle and by weakening of their cohesion with their parents.

\section{REFERENCES}

[1] Giddens, A. Sociology. (Cambridge: Polity Press 2006).Bargh, JA. McKenna, K. Y. A., Fitzsimons GM. 'Can You See the Real Me? Activation and Expression of the 'True Self' on the Internet' J. Soc. Issues. 58(1), 2002, pp.33-48.

[2] Glaser, J., Dixit, J. \& Green, D.P. 'Studying Hate Crime with the Internet: What Makes Racists Advocate Racial Violence?’ J. Soc. Issues. 58 (1), 2002, pp. 177-193.

[3] Hughes, R. Jr. \& Hans, JD. 'Computers, the Internet, and Families: A Review of the Role New Technology Plays in Family Life’ J. Fam.Issues. 22 (2), 2001, pp. 778-792.

[4] Orleans, M., \& Laney, M. C. (2000) 'Children's Computer Use in the Home: Isolation or Socialization?' Social Science Computer Review. 18 (3), 2000, pp. 56-72.

[5] Nie, N. and Erbring, L. (2000) 'Internet and Society: A Preliminary Report'.Stanford Institute for the Quantitative Study of Society: Stanford University. Retrieved May 2001(http://www.stanford.edu/group/siqss/Press_Release/Preliminary_Report-4-21.pdf).

[6] Joseph Turow and Lilach Nir, 'The Internet and the Family; The View From Parents, the View from Kids' A Report from the Annenberg Public Policy Center of the University of Pennsylvania. 35 (2), 2000, pp. 40-60.

[7] Lenhart, A., Raine, L., \& Oliver, L. (2001) 'Teenage Life Online: The Rise of the Instant-Message Generation and the Internet's Impact on Friendships and Family relationships' American Sociological Review. 38 (3), 2001, pp. 311-326.

[8] Livingstone, S. Young People and New Media: Children and the Changing Media Environment. (London: Sage, 2000).

[9] Mesch, G. S. 'The Internet and Intergenerational Relationships' Social Science Quarterly. 84, 2003, pp1038-1050.

[10] .Kaiser Family Foundation. Growing Up Wired: Survey of Youth and the Internet in the Silicon Valley. (Washington, DC: Author, 2003).

[11] Cole, J. I., Suman, M., Schram, P., Van Bel, D., Lun, B., Maguirre, P., Hanson, K., Singh, R.,\&Aquino, J. S.Surveying the Digital Future. (Los Angeles: UCLA Center for Communication Policy, 2000). http:// ccp.ucla.edu. [Accessed 1 October 2011]. 